\title{
Article \\ Overcoming Bottlenecks for Realizing a Vehicle-to-Grid Infrastructure in Europe through Standardization
}

\author{
Sameer Chandrakant Fulari (D) and Geerten van de Kaa *
}

Department of Values, Technology, and Innovation, Delft University of Technology, Jaffalaan 5, 2628 BX Delft, The Netherlands; sameerfulari@gmail.com

* Correspondence: g.vandekaa@tudelft.nl

Citation: Fulari, S.C.; van de Kaa, G. Overcoming Bottlenecks for Realizing a Vehicle-to-Grid Infrastructure in Europe through Standardization. Electronics 2021, 10, 582. https:// doi.org/10.3390/electronics10050582

Academic Editor: Sara Deilami

Received: 18 December 2020

Accepted: 18 February 2021

Published: 2 March 2021

Publisher's Note: MDPI stays neutral with regard to jurisdictional claims in published maps and institutional affiliations.

Copyright: (c) 2021 by the authors. Licensee MDPI, Basel, Switzerland. This article is an open access article distributed under the terms and conditions of the Creative Commons Attribution (CC BY) license (https:// creativecommons.org/licenses/by/ $4.0 /)$.

\begin{abstract}
This paper focuses on committee-market standards battles for the case of vehicle-to-grid technology in Europe. In this battle, standards such as CHArge de MOve (CHAdeMO) and Combined Charging System (CCS) Combo are competing. The paper identifies relevant factors with the help of a literature review and expert interviews. Furthermore, the importance weights were established for the factors. The paper ends with a discussion and conclusion in which the theoretical contributions, practical implications, limitations, and recommendations for further research are discussed.
\end{abstract}

Keywords: standards; standards battles; vehicle-to-grid technology; BWM; best-worst method

\section{Introduction}

The transportation sector is considered one of the significant contributors to the global carbon footprint [1], and most countries are moving toward the electrification of their transportation sector. Electric vehicles (EVs) became popular in the last decade. However, most of these vehicles are parked during peak hours when renewable energy generation through solar cells is optimal. This results in a tremendous amount of underutilized energy in the batteries of EVs. Vehicle-to-grid (V2G) technology [2,3] makes it possible to share that power with the grid. An essential aspect of V2G technology pertains to the charging equipment used to connect the EVs with the charging stations for charging and discharging (also known as bidirectional charging). Irrespective of the significant advantages of V2G technology, it is not being used on a large scale yet because no single dominant standard for charging is available.

Instead, various types of standards are competing against each other, including CHArge de MOve (CHAdeMO) and Combined Charging System (CCS) Combo. CHAdeMO, which originated in Japan and was developed by a consortium of auto manufacturers, is currently capable of bidirectional charging, while CCS Combo is expected to offer V2G charging by 2025 [4]. IEC, a formal standardization organization, developed the standards underlying CCS Combo. Although the charging stations around European countries include either or both of the two charging standards, the manufacturers of cars, home chargers, and home batteries are mostly implementing one standard. This may create high levels of potential uncertainty among consumers when buying these manufacturers' equipment, because the standard that is applied will become another decision criteria for consumers.

The decision for a standard will depend upon the value that it offers. This value may be determined by technological characteristics such as the charging time, but economic effects will also determine it. Network effects refer to a situation in which the value of technology increases the more it becomes adopted by other users. For example, the value will depend upon the number of charging stations that apply the same standard along the routes that are used by the consumers (direct network effects). The value will also depend upon the other products already owned by consumers that apply similar standards 
(indirect network effects). That makes the battle between standards such as CHAdeMO and CCS Combo an example of a standards battle or platform competition.

Typically, standards battles are between two or more single firms or consortia, such as in the case of VHS vs. Betamax [5]. What makes the standards battle discussed here unique is that the competing standards are not solely developed by market participants (the consortium behind CHAdeMO), but also by a formal standards committee (IEC for the CCS Combo) $[6,7]$. This type of battle will be referred to in this paper as a committee-market standards battle.

The main question in this paper is: According to experts, which factors affect the success of standards for $\mathrm{V} 2 \mathrm{G}$ charging in a committee-consortium standards battle? Our paper, based on a previous work [8], aims to answer this question by conducting a literature review and conducting expert interviews to identify the relevant factors for standard dominance. Furthermore, these factors' importance will be deduced by applying a multicriteria decision-making (MCDM) method. Various MCDM methods are available, including the analytic hierarchy process (AHP), ELimination Et Choix Traduisant la REalité (ELECTRE), and the Preference Ranking Organization METHod for Enrichment of Evaluations (PROMOTHEE) [9]. As the ELECTRE and PROMOTHEE methods are not suitable for cases in which decision-makers express their preferences [9], these methods were not chosen. The AHP method provides more robust solutions compared to ELELCTRE and PROMOTHEE, and would thus be favored. However, the AHP method requires a large number of comparisons. An efficient and modified version of AHP, the Best-Worst Method (BWM), was proposed recently by Rezaei (2015), and requires fewer comparisons. This method will be applied in this paper. Although newer versions of BWM [10,11] have been developed, we chose to apply the classic version of BWM because its applicability has been proven in various settings, including supply-chain management [12], innovation analysis [13], environmental management [14], water management [15], and R\&D [16].

Our paper will utilize insights from literature that has studied platform and de facto standards competition. Economists that study platform competition visualize the platform concept as a two-sided market [17]. The function of the platform is to connect the supply side with the demand side. Examples of platforms include operating systems or videogaming consoles. In two-sided markets, fierce competition occurs between platforms [18], leading to winner-take-all situations [19]. Often, direct and indirect network effects lead to a single platform that becomes the industry standard [19]. Various scholars have come up with factors that might influence the outcome of "platform wars" or standards battles [20].

Standardization scholars have shown that besides guaranteeing a certain amount of technological superiority over competitors, technologies compatible with other technologies may have an advantage over technologies that do not offer compatibility [21]. This compatibility can be between various technologies (horizontal compatibility) or between various generations of a single technology (vertical compatibility). It has also been shown that flexible standards have a favorable position [22].

Scholars in strategic management have pointed to the importance of characteristics of a platform's supporters. Financial strength, reputation and credibility, production capacity, and learning orientation are critical complementary assets required to win a standards battle. The brand reputation and credibility are related to trust and the credibility of the market's technology [23]. Strategy scholars also point to various strategies, including pricing, marketing, and the timing of entry.

Most of these scholars tend to agree on the importance of quickly establishing a sufficient amount of installed base [24,25]. Indeed, because of the network effects, the platform that achieves a sufficient amount of installed base before its competitors can pre-empt the market and establish platform success.

This paper contributes to the literature in various ways. First, this is one of the first times that committee-market standards battles have been studied. Our paper specifies five factors for standard success: brand reputation and credibility, compatibility, financial strength, lobbying, and the bandwagon effect, of which the latter three have not previously 
been found to be of importance in the context under investigation. Second, our paper focuses on standardization in the automotive industry, an industry that has been scarcely studied in the context of de facto standardization. Third, the paper contributes to previous research by analyzing the importance of factors in relation to the stage of the technologydominance process in which the battle is located. Finally, practitioners can use the results of this paper to decrease the uncertainty attached to choosing one technology or the other, or to manipulate its outcome.

\section{V2G Technology}

The concept of V2G technology was introduced by Kempton and Letendre in 1997 [3]. In a typical power grid, the power flows between energy producers through the power network to aggregators and homes. In the homes, power outlets provide energy to products such as electric vehicles. By default, the EVs should be able to connect to the grids to recharge their batteries. An electric vehicle that incorporates V2G technology can also provide energy back to the power outlet when the vehicle is parked. The EVs require additional setup to successfully return the power to the grid to perform this type of bidirectional charging.

Implementing a V2G architecture could potentially decrease the stability of the power grid. However, aggregators employ dispatch and control algorithms to optimize that stability and balance the energy distribution to the EVs. In that way, a vehicle can ultimately charge during the times when energy demand is low and discharge when it is high. However, the potential effect that this may have on the stability of the power grid has not been studied sufficiently [26]. Furthermore, the data that is collected can be susceptible to security issues, and privacy concerns among consumers might arise [27]. Ideally, these challenges will be addressed before the technology becomes adopted on a large scale.

The benefits of V2G technology are technical, economic, and environmental in nature. First, the grid's power storage capacity will increase gradually with the increase in the number of EVs sharing the power with the grid, allowing more power storage in the grid [28]. Second, the transition to V2G technology can replace 6.5 million barrels of oil usage per day, and it directly amounts to economic savings in a country [29]. Third, the transition can reduce greenhouse gases emitted by gasoline-based vehicles and promote EVs' usage in society [29].

The V2G systems need communication protocols to enable the transmission of instructions between the EVs and the electric vehicle supply equipment (EVSE). When the communication chips and protocols are in place to receive the signals, the aggregator can coordinate between the EVs and the electricity grid operator to regulate power supply and demand. The communication protocols related to EVs are divided into front-end and backend protocols [30]. The front-end protocols define the link between the EVs and EVSEs, and also specify the requirements related to charging topologies (such as type of charging equipment (on-board/off-board) and type of charging (conductive/inductive)), safety, charging plugs, communication, and cybersecurity [31]. A few examples of front-end protocols include IEC 61851, ISO 15118, SAE J2847, and CHAdeMO [28,31]. The back-end protocols define links between the EVs and third-party operators such as charge point operators (CPOs) (companies responsible for operating a pool of charging points [32]), and specify requirements related to communication and cybersecurity [31]. A few examples of back-end protocols include the open charge point protocol (OCPP), IEC 63110, the open automated demand response (ADR), and EEBUS [31]. More information on these standards can be found in [33].

To technically realize the V2G system, a simple communication chip is added to the onboard charger of the EVs to regulate the power flow between the EVs and the grid. However, designing this communication technology is expensive [28]. Therefore, most EVs are not equipped with these chips today, except for a few EVs manufactured by companies such as Nissan and Mitsubishi. Besides, energy meters capable of measuring the power flow between the grid and EVs accurately are required. For monitoring the 
real-time power flow, advanced metering infrastructure (AMI) is used to provide reliable information to aggregators and grid operators for managing the power flow in and out of the grid [28]. Currently, one technology, CHAdeMO, already offers V2G technology, while another technology, CCS Combo, is expected to offer V2G technology in the future.

\section{Methodology}

To answer our research question, we first conducted a literature study into factors for standard success in committee-market standards battles. In these battles, standard success refers, on the one hand, to the mere realization of a standard within a committee through, for example, consensus; and on the other hand, to the market dominance of a standard (e.g., in terms of installed base). Therefore, we searched for factors that influenced both of these aspects. Subsequently, we studied literature that analyzed the battle, and we interviewed three experts (Study 1). When a factor was mentioned in either one of the literature sources or by one of the experts, we considered that factor relevant, and we took the factor into account in the remainder of the study. Experts were allowed to come up with new factors that were not mentioned in the literature. Then, we applied a multicriteria decision-making method known as the best-worst method, in which seven experts assigned weights to all the relevant factors (Study 2). Finally, in Study 3, a third round of interviews was held in which the BWM results were discussed with four experts.

The experts that participated in this study and their characteristics can be found in Table 1. The last three columns indicate which respondent participated in which study.

Table 1. Respondents.

\begin{tabular}{|c|c|c|c|c|c|c|c|}
\hline$\#$ & Background & $\begin{array}{l}\text { Current } \\
\text { Function }\end{array}$ & $\begin{array}{c}\text { Years of } \\
\text { Experience }\end{array}$ & Degree & $\begin{array}{c}\text { Study } \\
1\end{array}$ & $\begin{array}{c}\text { Study } \\
2\end{array}$ & $\begin{array}{c}\text { Study } \\
3\end{array}$ \\
\hline 1 & Industry & V2G expert & 8 & $\begin{array}{c}\text { Mechanical } \\
\text { Engineering and } \\
\text { Engineering } \\
\text { Business } \\
\text { Administration } \\
\text { (EBA) }\end{array}$ & $x$ & $x$ & $x$ \\
\hline 2 & Industry & $\begin{array}{c}\text { Project } \\
\text { Manager, } \\
\text { Innovation }\end{array}$ & 7 & $\begin{array}{c}\text { Automotive } \\
\text { Engineer }\end{array}$ & $X$ & $x$ & $x$ \\
\hline 3 & Academia & $\begin{array}{l}\text { Senior } \\
\text { Research } \\
\text { Fellow }\end{array}$ & 18 & $\begin{array}{l}\text { Ph.D. in Electrical } \\
\text { Engineering and } \\
\text { Experimental } \\
\text { Physics }\end{array}$ & $X$ & $X$ & \\
\hline 4 & Academia & Researcher & 3 & $\begin{array}{c}\text { Masters in Solar } \\
\text { Photovoltaics } \\
\text { and Renewable } \\
\text { Energy }\end{array}$ & & $x$ & $x$ \\
\hline 5 & Academia & Professor & 7 & $\begin{array}{l}\text { Ph.D. in } \\
\text { Charging EVs } \\
\text { using Solar } \\
\text { Energy }\end{array}$ & & $x$ & \\
\hline 6 & Industry & ICT Architect & 6 & $\begin{array}{l}\text { Masters in } \\
\text { Technical } \\
\text { Informatics }\end{array}$ & & $X$ & \\
\hline 7 & Industry & $\begin{array}{c}\text { Project } \\
\text { Management } \\
\text { in V2G }\end{array}$ & 3 & $\begin{array}{c}\text { Masters in } \\
\text { Applied } \\
\text { Engineering (IT) }\end{array}$ & & $X$ & $X$ \\
\hline
\end{tabular}

Note: V2G = Vehicle-to-Grid. 


\section{BWM}

The (linear model) best-worst method (BWM) [34,35] was applied to determine the criteria weights. This method uses pairwise comparisons to arrive at weights for factors. This method was chosen because it leads to more reliable results than other methods [34]. Another advantage over other methods is that fewer comparisons are required. The BWM consists of five steps (the description is applied to the case under investigation):

Step 1: Determine the criteria $\left\{c_{1}, c_{2}, \ldots, c_{n}\right\}$. These criteria are the factors for standard dominance for the case of committee-market standards battles for V2G charging. These factors resulted from of the first stage of our analysis, in which the relevant criteria were sought by reviewing the literature and interviewing three experts.

Step 2: Determine the best and worst criteria. In other words, determine the most important and least important factors for standard success.

Step 3: Determine the preference of the criterion that is seen as the most important one over the other factors. Using pairwise comparisons, this is done by giving scores of 1 to 9 , where 1 refers to the same importance, and 9 refers to extremely less importance. These comparisons result in the best-to-others vector:

$$
A_{B}=\left(a_{B 1}, a_{B 2}, \ldots, a_{B n}\right)
$$

where $a_{B j}$ refers to the preference of the best criterion B over the criterion $j$.

Step 4: Determine the preference of each of the criteria over the worst criterion. Again, the expert has to use the numbers 1 to 9 , where 1 refers to the same importance while nine refers to extremely less importance. These comparisons result in the others-to-worst vector:

$$
A_{W}=\left(a_{1 W}, a_{2 W}, \ldots, a_{n W}\right)^{T}
$$

where $a_{j W}$ refers to the preference of criterion $\mathrm{j}$ over the worst criterion $W$.

Step 5: Determine the optimal weights of the factors for standard success. The value of optimal weights should satisfy the conditions, where for each pair of $w_{B} / w_{j}$ and $w_{j} / w_{W}$, we have $w_{B} / w_{j}=a_{B j}$ and $w_{j} / w_{W}=a_{j W}$. Furthermore, to satisfy the conditions for all $\mathrm{j}$, a solution is found in which the maximum absolute difference between $\left|\frac{w_{B}}{w_{j}}-a_{B j}\right|$ and $\left|\frac{w_{j}}{w_{W}}-a_{j W}\right|$ is minimized for all $\mathrm{j}$. In order to find these weights, the following problem (the converted optimization problem) should be solved:

$$
\min \xi^{L}
$$

s.t.

$$
\begin{gathered}
\left|w_{B}-a_{B J} w_{j}\right| \leq \xi^{L}, \text { for all } j \\
\left|w_{j}-a_{j W} w_{W}\right| \leq \xi^{L}, \text { for all } j \\
\sum_{j} w_{j}=1 \\
w_{j} \geq 0, \text { for all } j
\end{gathered}
$$

This results in a unique solution consisting of the optimal weights $\left(w_{1}{ }^{*}, w_{2}{ }^{*}, \ldots, w_{n}{ }^{*}\right)$. Furthermore, the consistency ratio $\xi^{*}$ is found. The closer that ratio is to zero, the higher the level of consistency of the model. This method is visualized in Figure 1. 


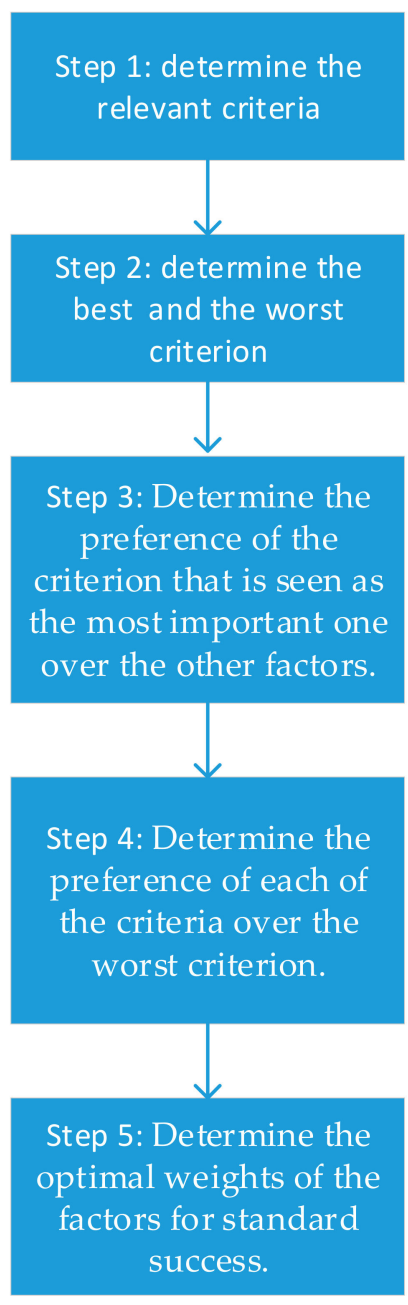

Figure 1. The best-worst method (BWM) procedure.

\section{Results}

Based on the literature review and expert interviews, a total of 35 factors were found to be relevant to standard success in committee-market standards battles for V2G technology. This list of factors was further classified into seven categories, partly based on previous categorizations for factors for standard dominance in Van de Kaa et al. (2011, 2020) [20,36]. The list of factors and their description can be found in Table 2.

Table 2. Factors for standard success for committee-market standards battles for V2G technology (as adopted from Fulari [8]).

\begin{tabular}{|c|c|}
\hline Factors & Description \\
\hline $\begin{array}{l}\text { Characteristics of the } \\
\text { standard supporter }\end{array}$ & $\begin{array}{l}\text { The first category of factors signifies the strength of the } \\
\text { standard supporter. }\end{array}$ \\
\hline 1. Financial strength & $\begin{array}{l}\text { Financial strength refers to the financial resources needed to } \\
\text { commercialize a standard successfully. }\end{array}$ \\
\hline $\begin{array}{l}\text { 2. Brand reputation } \\
\text { and credibility }\end{array}$ & $\begin{array}{l}\text { Both consumers and firms are more reluctant to adopt technology from } \\
\text { reputable companies. }\end{array}$ \\
\hline $\begin{array}{l}\text { 3. Operational } \\
\text { supremacy }\end{array}$ & $\begin{array}{l}\text { Production capacity is needed once the demand for the technology } \\
\text { increases. }\end{array}$ \\
\hline 4. Learning orientation & $\begin{array}{c}\text { By learning from previous experiences, firms can gain a better position } \\
\text { in the current battle. }\end{array}$ \\
\hline
\end{tabular}


Table 2. Cont.

\begin{tabular}{|c|c|}
\hline Factors & Description \\
\hline $\begin{array}{l}\text { Characteristics of the } \\
\text { standard }\end{array}$ & $\begin{array}{l}\text { This refers to the technological characteristics of the standard that make } \\
\text { it outcompete alternatives. }\end{array}$ \\
\hline $\begin{array}{l}\text { 5. Technological } \\
\text { superiority }\end{array}$ & $\begin{array}{l}\text { Technological superiority refers to the standard's technological } \\
\text { characteristics, which make it outperform its competitors [20]. }\end{array}$ \\
\hline 6. Compatibility & $\begin{array}{l}\text { Technology that is backward-compatible can use, for example, } \\
\text { complementary products of a previous generation, increasing potential } \\
\text { installed base [20]. }\end{array}$ \\
\hline 7. Flexibility & $\begin{array}{l}\text { Flexibility refers to the extent to which users' preferences are taken into } \\
\text { account in the standard, increasing the value of the standard to users; } \\
\text { as a result, the installed base might increase as the standard becomes } \\
\text { more attractive. }\end{array}$ \\
\hline $\begin{array}{l}\text { Standard support } \\
\text { strategy }\end{array}$ & $\begin{array}{l}\text { This refers to strategic maneuvering to establish dominance with the } \\
\text { standard }\end{array}$ \\
\hline 8. Pricing strategy & $\begin{array}{l}\text { Penetration pricing (below cost) can quickly amass an installed base } \\
\text { [20]. }\end{array}$ \\
\hline $\begin{array}{l}\text { 9.Appropriability } \\
\text { strategy }\end{array}$ & $\begin{array}{c}\text { Appropriability strategy refers, for example, to an open systems } \\
\text { strategy whereby access to valuable information about the standards is } \\
\text { given away for free, aiming at broad support for the standard [22], } \\
{[36,37] .}\end{array}$ \\
\hline 10. Timing of entry & $\begin{array}{l}\text { Timing of entry refers to when the standard is introduced in the market } \\
\text { [20]. If a standard is introduced before the competing standard is } \\
\text { introduced, it can quickly amass an installed base and effectively } \\
\text { pre-empt the market. }\end{array}$ \\
\hline $\begin{array}{l}\text { 11. Marketing } \\
\text { communications }\end{array}$ & $\begin{array}{l}\text { Marketing communications, such as pre-announcement strategies, are } \\
\text { used in a standards battle to increase the expected installed base [20]. }\end{array}$ \\
\hline $\begin{array}{l}\text { 12. Pre-emption of } \\
\text { scarce assets }\end{array}$ & $\begin{array}{l}\text { By entering early, firms can gain access to scarce assets in the form of, } \\
\text { for example, locations or people. }\end{array}$ \\
\hline $\begin{array}{l}\text { 13. Distribution } \\
\text { strategy }\end{array}$ & $\begin{array}{l}\text { Once the demand for the product increases, a proper distribution } \\
\text { system should be in place to make sure that the product is } \\
\text { sufficiently available }\end{array}$ \\
\hline 14. Commitment & $\begin{array}{l}\text { Standard supporters should be sufficiently committed to the standard's } \\
\text { success }[20,38] .\end{array}$ \\
\hline 15. Lobbying & $\begin{array}{l}\text { Lobbying refers to the "process of negotiating for favorable measures } \\
\text { directly to the concerned entity in the standardization process to } \\
\text { increase the speed of reaching consensus" [8]. }\end{array}$ \\
\hline $\begin{array}{l}\text { Factors influencing } \\
\text { committee consensus }\end{array}$ & $\begin{array}{l}\text { The "fourth category is mainly related to the factors that influence } \\
\text { building consensus within a committee in a standardization } \\
\text { process" [8]. }\end{array}$ \\
\hline 16. Voting rights & $\begin{array}{l}\text { The specific rules for voting in a committee may affect whether } \\
\text { consensus is achieved in that committee [39]. }\end{array}$ \\
\hline $\begin{array}{l}\text { 17. Incentives for } \\
\text { consensus-building }\end{array}$ & $\begin{array}{l}\text { Insufficient incentives for a stakeholder to reach consensus in a } \\
\text { committee can lead to delays in the standardization process }[40,41] \text {. }\end{array}$ \\
\hline $\begin{array}{l}\text { 18. Consensus rules in } \\
\text { the standardization } \\
\text { process }\end{array}$ & $\begin{array}{l}\text { A higher number of more stringent consensus rules can reduce the } \\
\text { chances that a standard is determined. }\end{array}$ \\
\hline $\begin{array}{l}\text { 19. Delay in the } \\
\text { standardization } \\
\text { process }\end{array}$ & $\begin{array}{l}\text { Delays reduce the likelihood of arriving at a consensus in } \\
\text { committees }[41,42] \text {. }\end{array}$ \\
\hline
\end{tabular}


Table 2. Cont.

\begin{tabular}{|c|c|}
\hline Factors & Description \\
\hline $\begin{array}{l}\text { 20. Number of } \\
\text { standard proposals } \\
\text { and revisions }\end{array}$ & $\begin{array}{l}\text { "Before reaching consensus, the committee follows a procedure of } \\
\text { reviewing all the number of proposals submitted by the members. If } \\
\text { there is no consensus on the current set of proposals, new revisions will } \\
\text { be prepared by the members and proposed in consecutive meetings. } \\
\text { This process continues until the final agreement is reached. Hence, it } \\
\text { leads to excessive delays until the proposals are not neutral, i.e., where } \\
\text { there are no conflicting interests [42]. Therefore, the higher the number } \\
\text { of standard proposals in the committee, the longer it takes to arrive at a } \\
\text { consensus." [8] }\end{array}$ \\
\hline $\begin{array}{l}\text { 21. Agenda-setting } \\
\text { effort }\end{array}$ & $\begin{array}{c}\text { "Agenda-setting can be used as a tool by any member in the } \\
\text { standardization process to align the interests and increase the } \\
\text { awareness about possible standards among stakeholders, which leads } \\
\text { to increased collaboration, eventually helping to reach a successful } \\
\text { consensus" }[8,43,44] .\end{array}$ \\
\hline Other Stakeholders & $\begin{array}{l}\text { The "fifth category of factors signifies the support from stakeholders } \\
\text { other than the standard supporters." [8]. }\end{array}$ \\
\hline $\begin{array}{l}\text { 22. Current installed } \\
\text { base }\end{array}$ & "Installed base refers to the number of users of a technology" [11,45]. \\
\hline $\begin{array}{l}\text { 23. Previous installed } \\
\text { base }\end{array}$ & $\begin{array}{l}\text { The previous installed base refers to the number of users of a previous } \\
\text { generation [20]. }\end{array}$ \\
\hline 24. Big Fish & $\begin{array}{l}\text { "A Big fish refers to a large company in the market that can have a } \\
\text { significant amount of influence in the standardization process by either } \\
\text { promoting or financing a particular standard" [8]. }\end{array}$ \\
\hline 25. Suppliers & $\begin{array}{l}\text { "Suppliers are market entities that produce complementary goods } \\
\text { based on the dominant standard in the market" [8]. }\end{array}$ \\
\hline 26. Regulator & Governments can enforce standards $[46,47]$. \\
\hline
\end{tabular}

"The sixth category pertains to the factors that cannot be influenced by Market characteristics any firm or group of firms but can be influenced by other entities in the market" [8].

\begin{tabular}{|c|c|}
\hline 27. Bandwagon effect & $\begin{array}{l}\text { When a sufficient number of users adopts a standard, a bandwagon } \\
\text { effect may occur where more users will adopt it }[20,48] \text {. }\end{array}$ \\
\hline $\begin{array}{l}\text { 28. Network } \\
\text { externalities }\end{array}$ & $\begin{array}{l}\text { The mechanism whereby the value of technology increases, the more it } \\
\text { is adopted [20]. }\end{array}$ \\
\hline $\begin{array}{l}\text { 29. Uncertainty in the } \\
\text { market }\end{array}$ & $\begin{array}{l}\text { Higher uncertainty is detrimental to the likelihood that dominant } \\
\text { standards will be arrived at [20]. }\end{array}$ \\
\hline 30. Rate of change & $\begin{array}{c}\text { The higher the rate of technological change, the higher market } \\
\text { uncertainty [20]. }\end{array}$ \\
\hline 31. Switching costs & Costs needed to switch from one standard to the other [20]. \\
\hline $\begin{array}{l}\text { 32. Community } \\
\text { development }\end{array}$ & $\begin{array}{l}\text { "Firms are increasingly dependent on the developer communities to } \\
\text { develop and diffuse IT-based standards, where they form a coalition } \\
\text { with those with similar interests. Hence it is necessary to build and } \\
\text { nurture the community of standard and application developers" [8] } \\
\text { based on [49]. "For example, Sun Microsystems allowed software } \\
\text { developers to learn Java with initiatives such as development tools and } \\
\text { courses" [8] based on [36]. "Hence, higher community development } \\
\text { can help the growth of a standard and eventually increase the } \\
\text { likelihood of selecting a dominant standard." [8] }\end{array}$ \\
\hline $\begin{array}{l}\text { Factors influencing the } \\
\text { committee } \\
\text { composition }\end{array}$ & $\begin{array}{l}\text { "The final category refers to the factors that influence the composition } \\
\text { of participants in a committee". [8] }\end{array}$ \\
\hline $\begin{array}{l}\text { 33. Size of the } \\
\text { committee }\end{array}$ & $\begin{array}{l}\text { The more members are involved in the standardization organization, } \\
\text { the higher the potential installed base [50-52]. }\end{array}$ \\
\hline
\end{tabular}


Table 2. Cont.

\begin{tabular}{cc}
\hline Factors & Description \\
\hline $\begin{array}{c}\text { 34. Network of } \\
\text { stakeholders }\end{array}$ & $\begin{array}{c}\text { A network of stakeholders refers to the diversity of the network in } \\
\text { terms of the industry representation. The higher the diversity, the } \\
\text { better [20], [53]. }\end{array}$ \\
\hline $\begin{array}{c}\text { 35. Number of } \\
\text { firm-specific } \\
\text { representatives in } \\
\text { the committee }\end{array}$ & $\begin{array}{c}\text { The higher the number of employees of specific firms present at } \\
\text { committee meetings, the higher the chance that these firms' proposals } \\
\text { can quickly be voted on, increasing the speed at which a standard is } \\
\text { determined [49]. }\end{array}$ \\
\hline
\end{tabular}

The results of the BWM analysis are reported in Table 3, which presents the weights of the factors Figure 2 presents an accompanying visualization. The consistency ratios were acceptable.

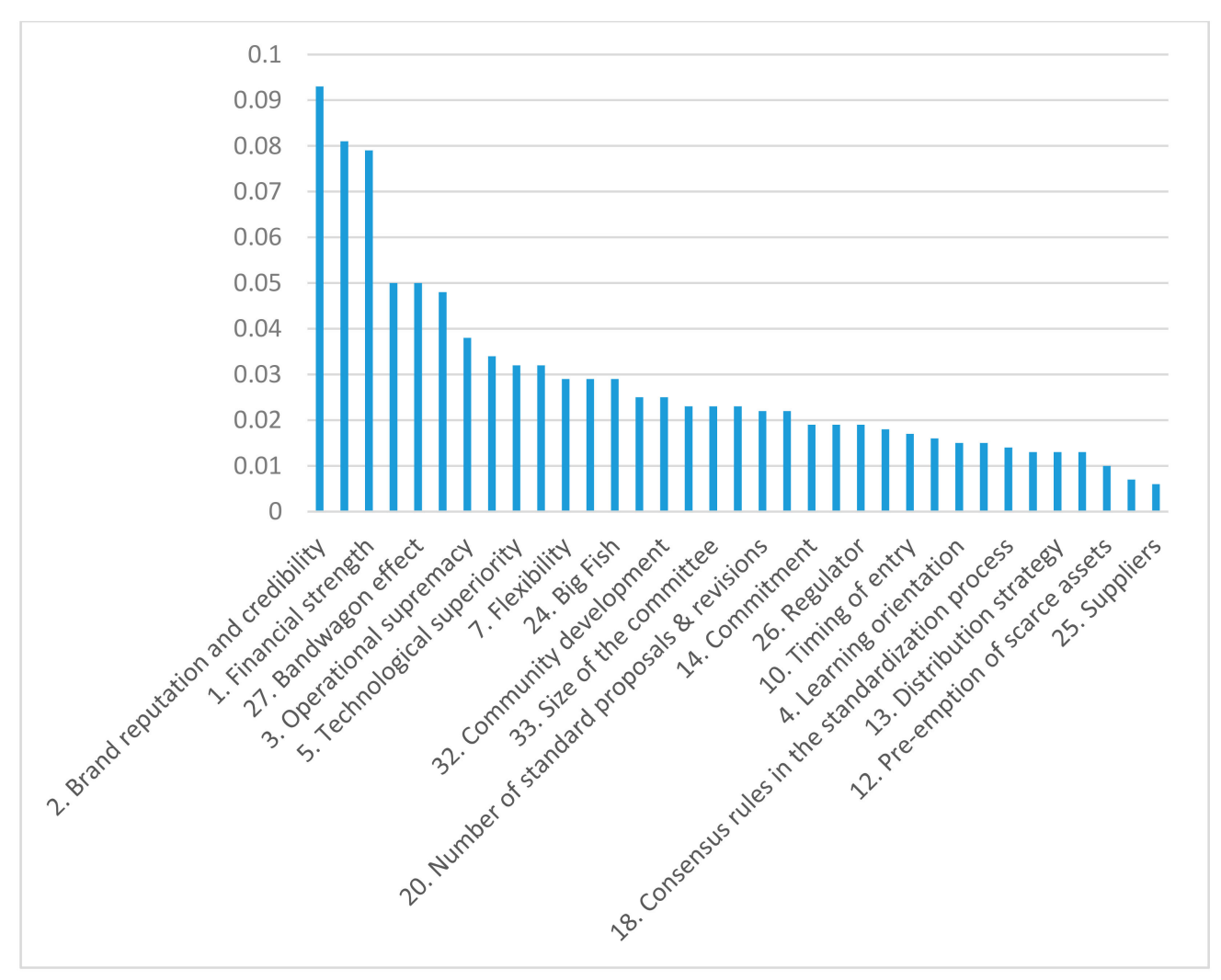

Figure 2. A visualization of the results ranking the factors from most important to least important.

\section{Interpretation of the Results}

The results showed that the factor "brand reputation and credibility" was the most important, with a weight of 0.093 . While V2G technology is a very new concept in the market, customers have yet to realize the technology's potential. Therefore, they heavily depend upon the companies' brand reputation in the service sectors [54]. According to one expert, "Brand value and credibility is also important because if other companies go to the vehicle-to-grid and your car cannot do it, the brand is slowly losing value. And also, when 51 people realize how much more green vehicle-to-grid is, compared to a car that's just charging. I think this is also something that will influence the brand absolutely" [8] (I1, 2020). Moreover, according to Fulari [8], the brand reputation also "plays a crucial role in a situation where both the technology development and its adoption are moving slowly in the market" ([8] based on [47]). A similar situation can be observed in developing V2G 
technology and EVs' adoption rate in the market. Therefore, "The brand reputation of the EV manufacturers involved in the development of V2G technology and charging standards have a significant role to play in attracting EV owners to adopt their standards" [8].

Table 3. Local and global weights per factor.

\begin{tabular}{|c|c|c|c|c|c|c|c|c|}
\hline Categories/Factors & Expert 1 & Expert 2 & Expert 3 & Expert 4 & Expert 5 & Expert 6 & Expert 7 & $\begin{array}{c}\text { Global } \\
\text { Average } \\
\text { Weight }\end{array}$ \\
\hline $\begin{array}{l}\text { Characteristics of the standard } \\
\text { supporter }\end{array}$ & 0.078 & 0.147 & 0.303 & 0.349 & 0.351 & 0.145 & 0.200 & 0.225 \\
\hline 1. Financial strength & 0.017 & 0.028 & 0.091 & 0.181 & 0.100 & 0.023 & 0.115 & 0.079 \\
\hline $\begin{array}{l}\text { 2. Brand reputation and } \\
\text { credibility }\end{array}$ & 0.043 & 0.042 & 0.157 & 0.109 & 0.175 & 0.080 & 0.046 & 0.093 \\
\hline 3. Operational supremacy & 0.006 & 0.068 & 0.036 & 0.044 & 0.050 & 0.031 & 0.028 & 0.038 \\
\hline 4. Learning orientation & 0.013 & 0.009 & 0.019 & 0.016 & 0.025 & 0.011 & 0.010 & 0.015 \\
\hline Characteristics of the standard & 0.194 & 0.073 & 0.114 & 0.086 & 0.085 & 0.357 & 0.080 & 0.141 \\
\hline 5. Technological superiority & 0.057 & 0.042 & 0.019 & 0.015 & 0.022 & 0.059 & 0.006 & 0.032 \\
\hline 6. Compatibility & 0.105 & 0.024 & 0.062 & 0.064 & 0.056 & 0.193 & 0.060 & 0.081 \\
\hline 7. Flexibility & 0.032 & 0.007 & 0.033 & 0.006 & 0.008 & 0.104 & 0.014 & 0.029 \\
\hline Standard support strategy & 0.027 & 0.375 & 0.038 & 0.214 & 0.213 & 0.217 & 0.133 & 0.174 \\
\hline 8. Pricing strategy & 0.003 & 0.025 & 0.003 & 0.017 & 0.014 & 0.007 & 0.022 & 0.013 \\
\hline 9. Appropriability strategy & 0.005 & 0.125 & 0.004 & 0.017 & 0.021 & 0.043 & 0.022 & 0.034 \\
\hline 10. Timing of entry & 0.007 & 0.012 & 0.012 & 0.015 & 0.043 & 0.029 & 0.003 & 0.017 \\
\hline 11. Marketing communications & 0.001 & 0.037 & 0.001 & 0.029 & 0.028 & 0.014 & 0.014 & 0.018 \\
\hline 12. Pre-emption of scarce assets & 0.002 & 0.021 & 0.007 & 0.006 & 0.012 & 0.012 & 0.007 & 0.010 \\
\hline 13. Distribution strategy & 0.002 & 0.030 & 0.002 & 0.015 & 0.017 & 0.017 & 0.007 & 0.013 \\
\hline 14. Commitment & 0.005 & 0.050 & 0.002 & 0.029 & 0.007 & 0.022 & 0.022 & 0.019 \\
\hline 15. Lobbying & 0.003 & 0.075 & 0.007 & 0.087 & 0.071 & 0.072 & 0.036 & 0.050 \\
\hline $\begin{array}{l}\text { Factors influencing committee } \\
\text { consensus }\end{array}$ & 0.118 & 0.220 & 0.091 & 0.143 & 0.107 & 0.031 & 0.032 & 0.106 \\
\hline 16. Voting rights & 0.018 & 0.083 & 0.037 & 0.046 & 0.010 & 0.003 & 0.003 & 0.029 \\
\hline $\begin{array}{l}\text { 17. Incentives for } \\
\text { consensus-building }\end{array}$ & 0.045 & 0.026 & 0.004 & 0.029 & 0.012 & 0.003 & 0.014 & 0.019 \\
\hline $\begin{array}{l}\text { 18. Consensus rules in the } \\
\text { standardization process }\end{array}$ & 0.011 & 0.035 & 0.006 & 0.029 & 0.009 & 0.004 & 0.002 & 0.014 \\
\hline $\begin{array}{l}\text { 19. Delay in the standardization } \\
\text { process }\end{array}$ & 0.027 & 0.017 & 0.022 & 0.019 & 0.004 & 0.005 & 0.005 & 0.015 \\
\hline $\begin{array}{l}\text { 20. Number of standard } \\
\text { proposals and revisions }\end{array}$ & 0.005 & 0.052 & 0.015 & 0.015 & 0.051 & 0.014 & 0.005 & 0.022 \\
\hline 21. Agenda-setting effort & 0.011 & 0.008 & 0.006 & 0.004 & 0.020 & 0.002 & 0.001 & 0.007 \\
\hline Other Stakeholders & 0.157 & 0.063 & 0.227 & 0.030 & 0.071 & 0.087 & 0.133 & 0.110 \\
\hline 22. Current installed base & 0.066 & 0.029 & 0.029 & 0.006 & 0.005 & 0.036 & 0.055 & 0.032 \\
\hline 23. Previous installed base & 0.038 & 0.017 & 0.058 & 0.001 & 0.003 & 0.021 & 0.022 & 0.023 \\
\hline 24. Big Fish & 0.019 & 0.008 & 0.102 & 0.006 & 0.035 & 0.014 & 0.017 & 0.029 \\
\hline 25. Suppliers & 0.007 & 0.003 & 0.015 & 0.003 & 0.007 & 0.006 & 0.005 & 0.006 \\
\hline 26. Regulator & 0.026 & 0.007 & 0.023 & 0.014 & 0.021 & 0.010 & 0.034 & 0.019 \\
\hline Market characteristics & 0.358 & 0.034 & 0.076 & 0.107 & 0.030 & 0.109 & 0.342 & 0.151 \\
\hline 27. Bandwagon effect & 0.136 & 0.017 & 0.031 & 0.026 & 0.012 & 0.048 & 0.081 & 0.050 \\
\hline 28. Network externalities & 0.032 & 0.007 & 0.009 & 0.017 & 0.008 & 0.006 & 0.032 & 0.016 \\
\hline 29. Uncertainty in the market & 0.080 & 0.003 & 0.007 & 0.010 & 0.004 & 0.019 & 0.027 & 0.022 \\
\hline 30. Rate of change & 0.040 & 0.004 & 0.012 & 0.003 & 0.003 & 0.014 & 0.013 & 0.013 \\
\hline 31. Switching costs & 0.054 & 0.003 & 0.012 & 0.042 & 0.001 & 0.010 & 0.054 & 0.025 \\
\hline 32. Community development & 0.016 & 0.001 & 0.003 & 0.007 & 0.003 & 0.011 & 0.135 & 0.025 \\
\hline $\begin{array}{l}\text { Factors influencing the committee } \\
\text { composition }\end{array}$ & 0.067 & 0.088 & 0.152 & 0.071 & 0.142 & 0.054 & 0.080 & 0.094 \\
\hline 33. Size of the committee & 0.020 & 0.008 & 0.013 & 0.013 & 0.092 & 0.004 & 0.009 & 0.023 \\
\hline 34. Network of stakeholders & 0.036 & 0.022 & 0.107 & 0.054 & 0.035 & 0.032 & 0.051 & 0.048 \\
\hline $\begin{array}{l}\text { 35. Number of firm-specific } \\
\text { representatives in the committee }\end{array}$ & 0.011 & 0.058 & 0.032 & 0.005 & 0.016 & 0.018 & 0.020 & 0.023 \\
\hline
\end{tabular}


The second most crucial factor was "compatibility" (0.081), which refers to whether the charging equipment can charge across different countries, in which case it provides "an edge over the competitors in the market" ([8] based on [55]). Furthermore, providing backward-compatibility with previous versions of the charging equipment is an important aspect to gain dominance in the market. As one respondent noted, "The charging equipment is seen as a piece of add-on equipment to the electric cars" [8] (I11, 2020); the standard that is most compatible will be adopted by consumers and EV manufacturers [8].

The factor "financial strength" was the third most important factor (0.079). Without continuous investments in developing a standard, companies cannot sustain themselves in the market $[41,42]$. Therefore, to realize success with the standard, continuous investments in, for example, establishing a charging infrastructure are needed. One of the experts argued, "You need deep pockets to provide these services" [39] (I10, 2020). Financial resources can also be used as a tool for lobbying to gather "more support from other players in the market" $[8,56]$. While there is competition in the market between the charging standards, having V2G capability can provide a competitive advantage to either of the charging standards. Therefore, one of the experts mentioned that, "The financial strength is absolutely important when we get a bit of competition in this field" [8] (I1, 2020).

The fourth most important factor was "lobbying" (0.050). While lobbying has been considered to be of great importance in committees, an expert mentioned that, "Because I think every car manufacturer will have its ideas on how, for example, vehicle-to-grid should take place and how safety devices should be implemented in a standard. So for those specific decisions, lobbying is very important" [8] (I2, 2020). However, the decision is based on reaching a consensus among the participants of the standardization process. According to Fulari [8], "Lobbying is used by technology producers to gain support from other stakeholders to reach an agreement, which in turn helps them to obtain a dominant position within the committee." In the context of charging standards, "Lobbying can also be used as a tool by the alliances" [8], supporting one particular standard to negotiate with the government agencies. Such a type of negotiation involves regulating one standard to avoid competing against other players in the market. Lobbying can be used by EV manufacturers to persuade EU policymakers to provide incentives for purchasing EVs to consumers in Europe. While various actors are involved in developing V2G technology, each actor uses lobbying as a tool to propose their ideas to the respective actors. The role of lobbying in this particular battle is evident. For example, ISO focuses on setting agreements for V2G standards with the committee members [8].

The fifth most important factor was "bandwagon effects" (0.050). One of the experts mentions that, "They [big OEMs] look a lot at each other. I'm very sure this had an effect on the others already, even though we don't see the vehicle-to-grid as much on the other one, so I'm sure this will have an effect on the others, that's for sure" [8] (I1, 2020). In a similar context, I11 (2020) indicated that, "The 'bandwagon effect' has been seen in the market already. A bunch of automobile manufacturers have chosen one of the charging standards, just because the majority has chosen one of the standards in the battle" [8]. Such an effect could continue until a dominant standard is selected in the battle. Although in Europe, various electric cars have been sold in the last decade, the market share of gasoline-based vehicles continues to dominate the market. With the increase in awareness among the drivers about the benefits obtained from EVs, EV market shares are estimated to increase soon [57]. In addition, almost $76 \%$ of consumers in a study believed that the EV industry will see a significant increase in the market share in the next five years, but is not ready for the present market [58]. Therefore, a potential bandwagon effect is predicted in the next five years, which will increase the adoption of EVs and V2G technology.

In summary, five factors for standard success are especially important: brand reputation and credibility, compatibility, financial strength, lobbying, and the bandwagon effect. 


\section{Discussion and Conclusion}

This paper was built on a previous work [8]. It found five factors of standard importance that are especially important for V2G charging: brand reputation and credibility, compatibility, financial strength, lobbying, and the bandwagon effect. Two factors have been found in previous research that has studied factors for standard dominance in the automotive sector: brand reputation and credibility and compatibility were found to be of importance in the battle between battery-powered and fuel-cell-powered electric vehicles) [59], while three factors have not previously been found to be of importance in this sector (financial strength, lobbying, and the bandwagon effect). Furthermore, the top four factors are usually also relevant in market-based standardizations. Few factors that are specifically relevant for committee-based standardization seem to be relevant to the specific type of standards battle that we studied in this paper; namely, committee-market battles.

Suarez [60] argued that the technology-dominance process is divided into five stages. While the first stage starts with a first organization doing applied research, the second stage starts when a first prototype has been developed. The third stage begins when a first commercial product has been developed and lasts until a clear early frontrunner marks the fourth stage. That stage lasts until a dominant standard has arrived. The battle studied in this paper is in the third stage, when a commercial product has entered the market (the Nissan Leaf). According to Suarez [60], strategic maneuvering is essential in that stage, while complementary assets such as brand reputation and credibility are most important in the first stage. We found that this factor remained vital until the third stage.

This is the first time that factors for standard dominance in the context of committeemarket battles have been studied. Future research could study similar committee-market standards battles and apply the framework developed in this paper as a starting point. Then, the framework could be further tested and empirically validated. Furthermore, combinations of factors can affect standard dominance [61]. For example, network effects moderate the influence of an installed base on standard success, and financial resources are needed to follow a marketing campaign. These effects have been observed in cases, but empirical research in which the underlying hypotheses are tested is scarce; this could be an area for future research.

Various methods can be used in such research, ranging from case studies to the kind of methods used in the current paper. That research could also potentially lead to new factors relevant to the specific case that we studied.

The amount of currently available protocols for $\mathrm{V} 2 \mathrm{G}$ technology increases the uncertainty with regard to choosing one or the other technology for practitioners. Future research can, when a sufficient number of standards are mature and are available on the market, attempt to decrease that uncertainty by applying the framework to various standards in order to arrive at an indication of which standard will have the highest chance of achieving dominance.

The paper contributes to this theory and the practice of standardization in several ways. First, this is the first time a list of factors for standard dominance for committeemarket standards battles was developed, and weights for these factors were assigned for a specific case. Second, the topic of standards battles and platform competition has been studied thoroughly by management and economics scholars, but mostly in the consumer electronics, telecommunications, and IT industries [62]. This study's contribution is that it focused on a novel empirical context that has only scarcely been studied concerning platform competition - the automotive industry. The results partly confirmed previous research into technology battles for battery-powered and fuel-cell-powered electric vehicles, in which compatibility and brand reputation and credibility were also important. Our results also provide evidence of the importance of three other factors.

Author Contributions: Conceptualization, S.C.F. and G.v.d.K.; methodology, S.C.F. and G.v.d.K.; validation, S.C.F. and G.v.d.K.; Writing-Original draft preparation, S.C.F.; Writing-Review and editing, S.C.F. and G.v.d.K. All authors have read and agreed to the published version of the manuscript.

Funding: This research received no external funding. 
Informed Consent Statement: Informed consent was obtained from all subjects involved in the study.

Data Availability Statement: The data presented in this study are available on request from the corresponding author. The data are not publicly available but stored on the data storage of the Technical University Delft.

Conflicts of Interest: The authors declare no conflict of interest.

\section{References}

1. EPA-United States Environmental Protection Agency. Sources of Greenhouse Gas Emissions. Available online: https://www.epa. gov/ghgemissions/sources-greenhouse-gas-emissions (accessed on 9 March 2020).

2. Lauinger, D.; Vuille, F.; Kuhn, D. A review of the state of research on vehicle-to-grid (V2G): Progress and barriers to deployment. In Proceedings of the European Battery, Hybrid and Fuel Cell Electric Vehicle Congress, Geneva, Switzerland, 14-16 March 2017; pp. 1-8.

3. Kempton, W.; Letendre, S.E. Electric vehicles as a new power source for electric utilities. Transp. Res. Part. D Transp. Environ. 1997, 2, 157-175. [CrossRef]

4. Kane, M. “CharIN: CCS Combo Standard To Offer V2G By 2025,” InsideEvs.com, 23 January 2019. Available online: https: //insideevs.com/news/342354/charin-ccs-combo-standard-to-offer-v2g-by-2025/ (accessed on 11 April 2020).

5. Cusumano, M.A.; Mylonadis, Y.; Rosenbloom, R.S. Strategic Maneuvering and Mass-Market Dynamics: The Triumph of VHS over Beta. Bus. Hist. Rev. 1992, 66, 51-94. [CrossRef]

6. Bakker, S.; Maat, K.; Van Wee, B. Stakeholders interests, expectations, and strategies regarding the development and implementation of electric vehicles: The case of the Netherlands. Transp. Res. Part. A: Policy Pr. 2014, 66, 52-64. [CrossRef]

7. Bakker, S.; Trip, J.J. An Analysis of the Standardization Process of Electric Vehicle Recharging Systems. Green Energy and Technology 2015, 203, 55-71. [CrossRef]

8. Fulari, S.C. Factors influencing the success within multi-mode standardization for selecting the Vehicle-to-Grid (V2G) charging standards. Master's Thesis, Delft University of Technology, Delft, The Netherlands, 2020.

9. Sabaei, D.; Erkoyuncu, J.; Roy, R. A Review of Multi-criteria Decision Making Methods for Enhanced Maintenance Delivery. Procedia CIRP 2015, 37, 30-35. [CrossRef]

10. Brunelli, M.; Rezaei, J. A multiplicative best-worst method for multi-criteria decision making. Oper. Res. Lett. 2019, 47, 12-15. [CrossRef]

11. Mohammadi, M.; Rezaei, J. Bayesian best-worst method: A probabilistic group decision making model. Omega $2020,96,102075$. [CrossRef]

12. Ahmadi, H.B.; Kusi-Sarpong, S.; Rezaei, J. Assessing the social sustainability of supply chains using Best Worst Method. Resour. Conserv. Recycl. 2017, 126, 99-106. [CrossRef]

13. Gupta, H.; Barua, M.K. Identifying enablers of technological innovation for Indian MSMEs using best-worst multi criteria decision making method. Technol. Forecast. Soc. Chang. 2016, 107, 69-79. [CrossRef]

14. Gupta, H. Assessing organizations performance on the basis of GHRM practices using BWM and Fuzzy TOPSIS. J. Environ. Manag. 2018, 226, 201-216. [CrossRef]

15. Chitsaz, N.; Azarnivand, A. Water Scarcity Management in Arid Regions Based on an Extended Multiple Criteria Technique. Water Resour. Manag. 2016, 31, 233-250. [CrossRef]

16. Salimi, N.; Rezaei, J. Evaluating firms' R\&D performance using best worst method. Eval. Program. Plan. 2018, 66, 147-155. [CrossRef]

17. Rochet, J.-C.; Tirole, J. Platform Competition in Two-Sided Markets. J. Eur. Econ. Assoc. 2003, 1, 990-1029. [CrossRef]

18. Armstrong, M. Competition in two-sided markets. RAND J. Econ. 2006, 37, 668-691. [CrossRef]

19. Hill, C.W.L. Establishing a standard: Competitive strategy and technological standards in winner-take-all industries. Acad. Manag. Perspect. 1997, 11, 7-25. [CrossRef]

20. Van De Kaa, G.; Ende, J.V.D.; De Vries, H.J.; Van Heck, E. Factors for winning interface format battles: A review and synthesis of the literature. Technol. Forecast. Soc. Chang. 2011, 78, 1397-1411. [CrossRef]

21. Lee, J.; Lee, J.; Lee, H. Exploration and Exploitation in the Presence of Network Externalities. Manag. Sci. 2003, 49, 553-570. [CrossRef]

22. Ende, J.V.D.; Van De Kaa, G.; Uijl, S.D.; De Vries, H.J. The Paradox of Standard Flexibility: The Effects of Co-evolution between Standard and Interorganizational Network. Organ. Stud. 2012, 33, 705-736. [CrossRef]

23. Ciaian, P.; Rajcaniova, M.; Kancs, D. The economics of BitCoin price formation. Appl. Econ. 2015, 48, 1799-1815. [CrossRef]

24. Shapiro, C.; Varian, H.R. Information Rules, a Strategic Guide to the Network Economy; Harvard Business Review Press: Boston, MA, USA, 1999.

25. Shapiro, C.; Varian, H.R. The Art of Standards Wars. Calif. Manag. Rev. 1999, 41, 8-32. [CrossRef]

26. Peng, C.; Zou, J.; Lian, L. Dispatching strategies of electric vehicles participating in frequency regulation on power grid: A review. Renew. Sustain. Energy Rev. 2017, 68, 147-152. [CrossRef]

27. Saxena, N.; Grijalva, S.; Chukwuka, V.; Vasilakos, A.V. Network Security and Privacy Challenges in Smart Vehicle-to-Grid. IEEE Wirel. Commun. 2017, 24, 88-98. [CrossRef] 
28. Noel, L.; de Gerardo, Z.R.; Kester, J.; Sovacool, B.K. Vehicle-to-Grid: A Sociotechnical Transition beyond Electric Mobility, Springer: Cham, Switzerland, 2019.

29. Sovacool, B.K.; Hirsh, R.F. Beyond batteries: An examination of the benefits and barriers to plug-in hybrid electric vehicles (PHEVs) and a vehicle-to-grid (V2G) transition. Energy Policy 2009, 37, 1095-1103. [CrossRef]

30. Schmutzler, J.; Andersen, C.A.; Wietfeld, C. Evaluation of OCPP and IEC 61850 for Smart Charging Electric Vehicles. World Electr. Veh. J. 2013, 6, 863-874. [CrossRef]

31. Neaimeh, M.; Andersen, P.B. Mind the gap- open communication protocols for vehicle grid integration. Energy Inform. 2020, 3, 1-17. [CrossRef]

32. Virta Global. The Two Sides of EV Charging Network Operators. 2019. Available online: https://www.virta.global/blog/thetwo-sides-of-ev-charging-network-operators\#: \{\}:text=A\%20Charge \%20Point $\% 20$ Operator $\% 20(\mathrm{CPO}, \% 20 \mathrm{describe} \% 20 \mathrm{a} \% 20$ Charge\%20Point\%20Owner (accessed on 8 February 2021).

33. Energy Informatics. Table 2 Protocols for Vehicle Grid Integration. 2020. Available online: https://energyinformatics. springeropen.com/articles/10.1186/s42162-020-0103-1/tables/2 (accessed on 8 February 2021).

34. Rezaei, J. Best-worst multi-criteria decision-making method. Omega 2015, 53, 49-57. [CrossRef]

35. Rezaei, J. Best-worst multi-criteria decision-making method: Some properties and a linear model. Omega 2016, 64, 126-130. [CrossRef]

36. Garud, R.; Jain, S.; Kumaraswamy, A. Institutional Entrepreneurship in the Sponsorship of Common Technological Standards: The Case of Sun Microsystems and Java. Acad. Manag. J. 2002, 45, 196-214. [CrossRef]

37. Ranganathan, R.; Ghosh, A.; Rosenkopf, L. Competition-cooperation interplay during multifirm technology coordination: The effect of firm heterogeneity on conflict and consensus in a technology standards organization. Strat. Manag. J. 2018, 39, 3193-3221. [CrossRef]

38. Farrell, J.; Saloner, G. Coordination through Committees and Markets. RAND J. Econ. 1988, 19, 235. [CrossRef]

39. Uijl, S.D.; De Vries, H.J. Pushing technological progress by strategic manoeuvring: The triumph of Blu-ray over HD-DVD. Bus. Hist. 2013, 55, 1361-1384. [CrossRef]

40. Blind, K.; Mangelsdorf, A. Motives to standardize: Empirical evidence from Germany. Technovation 2016, 48-49, 13-24. [CrossRef]

41. Van De Kaa, G.; De Bruijn, H. Platforms and incentives for consensus building on complex ICT systems: The development of WiFi. Telecommun. Policy 2015, 39, 580-589. [CrossRef]

42. Simcoe, T. Committees and the Creation of Technical Standards. 2003. Available online: http://citeseerx.ist.psu.edu/viewdoc/ download;jsessionid=5FD6F7A2E51048F2AA4971845D6ED57A?doi=10.1.1.201.9814\&rep=rep1\&type=pdf (accessed on 8 February 2021).

43. Meyer, N. Public intervention in private rule-making: The role of the European Commission in industry standardization," London School of Economics and Political Science for the Degree of Doctor of Philosophy. 2012. Available online: https: //core.ac.uk/download/pdf/4187684.pdf (accessed on 8 February 2021).

44. Van De Kaa, G.; Eijnden, L.V.D.; Doorn, N. Filtering Out Standard Success Criteria in the Case of Multi-Mode Standardization: Responsible Waste Water Treatment. Sustainability 2020, 12, 1641. [CrossRef]

45. Van de Kaa, G. Standards Battles Empirical Research on the Home Network; Erasmus Research Institute of Management (ERIM): Rotterdam, The Netherlands, 2009.

46. De Vries, H.J.; De Ruijter, J.P.; Argam, N. Dominant design or multiple designs: The flash memory card case. Technol. Anal. Strat. Manag. 2011, 23, 249-262. [CrossRef]

47. Gandal, N.; Salant, D.; Waverman, L. Standards in wireless telephone networks. Telecommun. Policy 2003, 27, 325-332. [CrossRef]

48. Mattli, W.; Büthe, T. Setting International Standards: Technological Rationality or Primacy of Power? World Politics 2003, 56, 1-42. [CrossRef]

49. Fukami, Y.; Shimizu, T. Innovating through standardization: How Google Leverages the Value of Open Digital Platforms. In Proceedings of the 22nd Pacific Asia Conference on Information Systems-Opportunities and Challenges for the Digitized Society, Yokohama, Japan, 26-30 June 2018; pp. 2273-2285.

50. Axelrod, R.; Mitchell, W.; Thomas, R.E.; Bennett, D.S.; Bruderer, E. Coalition Formation in Standard-Setting Alliances. Manag. Sci. 1995, 41, 1493-1508. [CrossRef]

51. Dan, S.M. How interface formats gain market acceptance: The role of developers and format characteristics in the development of de facto standards. Technovation 2019, 88, 102054. [CrossRef]

52. Hail, L.; Leuz, C.; Wysocki, P.D. Global Accounting Convergence and the Potential Adoption of IFRS by the U.S. (Part II): Political Factors and Future Scenarios for U.S. Accounting Standards. Account. Horizons 2010, 24, 567-588. [CrossRef]

53. De Vries, H.J.; Verhagen, W.P. Impact of changes in regulatory performance standards on innovation: A case of energy performance standards for newly-built houses. Technovation 2016, 48-49, 56-68. [CrossRef]

54. Hem, L.E.; De Chernatony, L.; Iversen, N.M. Factors Influencing Successful Brand Extensions. J. Mark. Manag. 2003, 19, 781-806. [CrossRef]

55. Choi, S.C.; Lim, K.S.; Yu, P.I. Strategic joint ventures with developing country in battles for technical standards. Jpn. World Econ. 1999, 11, 135-149. [CrossRef]

56. Victor, J.N. Strategic Lobbying. Am. Politics Res. 2007, 35, 826-845. [CrossRef] 
57. Tsakalidis; Thiel, C. Electric Vehicles in Europe from 2010 to 2017: Is Full-Scale Commercialisation Beginning? An Overview of the Evolution of Electric Vehicles in Europe; EUR 29401 EN; Publications Office of the European Union: Luxembourg, 2018; ISBN 978-92-79-96719-1. [CrossRef]

58. Boilard, M.; Confais, E. Why Electric Vehicle Sales Are About To Take Off. 2019. Available online: https:/ /www.oliverwyman. com/our-expertise/insights/2019/jun/automotive-manager-2019/customer/why-electric-vehicle-sales-are-about-to-takeoff.html (accessed on 4 August 2020).

59. Van De Kaa, G.; Scholten, D.; Rezaei, J.; Milchram, C. The Battle between Battery and Fuel Cell Powered Electric Vehicles: A BWM Approach. Energies 2017, 10, 1707. [CrossRef]

60. Suarez, F.F. Battles for technological dominance: An integrative framework. Res. Policy 2004, 33, 271-286. [CrossRef]

61. Papachristos, G.; Van De Kaa, G. A System Dynamics Model of Standards Competition. IEEE Trans. Eng. Manag. 2021, 68, 18-32. [CrossRef]

62. Rietveld, J.; Schilling, M.A. Platform Competition: A Systematic and Interdisciplinary Review of the Literature. J. Manag. 2020, XX, 014920632096979. [CrossRef] 